\title{
My Prison Experiences and What Keeps Me Struggling
}

Sundiata Acoli

• am a 70 year old PP/POW and counting jail time i've spent 35 years, lover half my life, in prison. Most were the highest security prisons in the state, Trenton State Prison, New Jersey, or the highest security prison in the country at the time, the federal penitentiary, USP Marion, Illinois. Other prisons i've done stretches at are USP Leavenworth, Kansas, followed by USP Allenwood at White Deer, Pennsylvania, where i'm presently held and have been for the last 12 years.

So i've seen prisons and i've seen many years behind bars. During my long sojourn, i've seen prisons change for the better and the worse, seen prisoners stand tall and prisoners sell out, and i've seen prisoners struggling in solidarity and at other times seen them apathetic, divided and demoralized.

In fact, i've just about seen it all: prison rebellions; takeovers; hostagetaking; lockdowns; guard brutality and atrocities; racial wars and gang wars; escapes and attempts; guards killing prisoners and prisoners killing guards; prison rights struggles that won significant gains in the 1960s and 1970s, government retrenchment in the 1980s and 1990s, and the turn of the century that retook most of the earlier won benefits; the rise of AIDS; rats and confidential informants; prison overcrowding; prison building sprees and the prison industrial complex (PIC); parole boards and the abolishment of parole boards. In a word, there isn't much about prison and prison struggles that $\mathrm{i}$ haven't seen.

And what have i learned in all these years of prison and struggles seen? i've learned that prison struggle, like all struggle, is cyclic; it ebbs and flows and will rise again.

As it is outside, so it is inside. The source of the problem has not been resolved, so it's only a matter of time, of rebuilding, regrouping and regrowing another generation until the struggle intensifies again, inside and out.

And now, what keeps me struggling after all these years? Well, i'm a revolutionary, and struggle is what $\mathrm{i}$ do. When i joined the Black Panther Party and stepped upon the path of revolution, i knew that the likely outcome would be prison or death, with freedom in my lifetime only a slim possibility. And i know that some of my comrades of the time were of a similar mindset.

We took Malcolm's dictum to heart; hell, we didn't care about odds. We knew our cause was right, and we wanted to fight! For our people, for 
ourselves, for others oppressed, those long dead and the ones unborn - and we did!

It felt and feels good to fight! How could it not feel good to fight someone who's had his foot on your neck, your momma's neck, your people's neck and other oppressed people's neck for 500, 1,000, 2,000 years and more? And he still has his foot on our necks. i know he still has his foot on my neck, and i know the struggle is going to intensify, inside and out, and $\mathrm{i}$ know that one day we will win-so i keep struggling.

Sundiata Acoli, formerly known as Clark Squire, is a New Afrikan POW. He is imprisoned for actions carried out in the fight for Black Liberation. In 1968 Sundiata joined the Harlem branch of the Black Panther Party (BPP) and did work around the issues of education, housing, employment, child care, drugs and police brutality in the oppressed community. In 1969 he was imprisoned with 13 others in what was known as the Panther 21 case for charges motivated by community work. Held for two years without bail, the Panther 21 were acquitted and Sundiata was released in 1971. Upon being released, Sundiata was harassed, provoked and followed by the FBI until it was impossible to do effective community work. He then joined the Black underground with the Black Liberation Army (BLA). In May 1973 Sundiata, with Zayd Malik Shakur and Assata Shakur, were ambushed on the NJ Turnpike by state troopers. Zayd was murdered by the police, Assata critically wounded. In the shootout a trooper was killed. Sundiata escaped this incident but was captured shortly after and is now serving a life plus 30 year sentence for the killing of the state trooper.

Write: Sundiata Acoli

\#39794-066

USP Allenwood

PO Box 1000

White Deer, PA 17837

(text from http://www.mxgm.org/politicaled.htm) 